\section{Seksualatferd og klamydia blant ungdom i Finnmark}

Skolescreening for genital klamydia avslører mange infiserte.

Genital klamydiainfeksjon er oftest asymptomatisk, og ubehandlet infeksjon hos kvinner kan føre til svangerskap utenfor livmoren og barnløshet. Ifølge overvåkingsdata fra Folkehelseinstituttet har Finnmark hatt landets høyeste forekomst av klamydia.

I 2009 gjennomførte vi en tverrsnittsstudie ved hjelp av web-baserte spørreskjemaer og innsamling av urinprøver i 123 klasser ved fem videregående skoler i Finnmark. Vi benyttet en høyoppløselig genotypimetode (multilokussekvenstyping, MLST) til å kartlegge hvilke bakteriegenotyper som sirkulerer i en seksuelt aktiv ungdomspopulasjon. Klamydiaprevalens var 7,3\% hos jenter og $3,9 \%$ hos gutter. Jentene hadde tidligere seksuell debut, oftere ubeskyttet sex og oftere fast eldre partner enn jevnaldrende gutter. Ulikheter i tidlig seksualatferd kan bidra til å forklare kjønnsforskjeller i prevalens. Tre ganger flere jenter $(56 \%)$ enn gutter $(20 \%)$ rapporterte tidligere testing i klinisk praksis, mens deltakelse $i$ vår skolescreeningstudie var lik for jenter og gutter (93\%). Tidligere testing var knyttet til kjente risikofaktorer for klamydia, som tidlig seksuell debut, ubeskyttet sex og mange partnere. Halvparten av infeksjonene som ble funnet $i$ vår studie, ble påvist hos deltakere som tidligere ikke hadde vært testet. MLST påviste stor genetisk variasjon og mange nye genotyper i et tidligere ikke kartlagt område.

Skolescreeningen økte andelen testede av begge kjønn og påviste et stort skjult infeksjonsreservoar. Effekt av skolescreening bør undersøkes nærmere i selekterte områder med høy klamydiaforekomst, og slik screening bør vurderes som et tillegg til andre forebyggende tiltak mot klamydia i Norge.

\section{Kirsten Gravningen}

Kirsten.Gravningen@unn.no

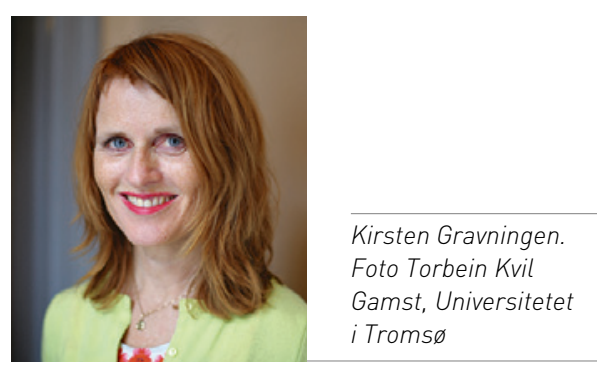

Disputas

Kirsten Gravningen disputerte for ph.d.-graden ved Universitetet i Troms $\varnothing$ - Norges arktiske universitet 6.12. 2013. Tittelen på avhandlingen er Genital Chlamydia infections among adolescents in a high-incidence area in Norway: genotypes, prevalence, early sexual behaviour and testing patterns - a cross sectional study. The Finnmark High School Study.

\title{
Vektreduksjon og røykekutt mot halsbrann
}

Halsbrann og sure oppstøt forekommer hyppig og er økende i befolkningen, men vektreduksjon og røykekutt kan bedre plagene.

Halsbrann og sure oppstøt er hovedsymptomene ved gastroøsofageal reflukssykdom. Reflukssykdom forekommer hyppig og er assosiert med redusert livskvalitet og arbeidsevne og økt risiko for adenokarsinom i distale oesophagus. Medikamentell behandling mot reflukssykdom er vanligvis effektiv, men behandlingen er ofte langvarig og kostnadene betydelige. Spesielt protonpumpehemmere har også bivirkninger ved langtidsbruk, som økt infeksjonsrisiko og malabsorpsjon av mineraler og elektrolytter.

Helseundersøkelsen i Nord-Trøndelag (HUNT) viste at forekomsten av halsbrann og sure oppstøt er betydelig og økende i befolkningen. Fra 1995-1997 (HUNT 2) til 2006-2008 (HUNT 3) økte andelen personer som hadde reflukssymptomer minst én gang ukentlig med $47 \%$, fra $11,6 \%$ til $17,1 \%$. Likevel ser vi at de personene som går ned i vekt eller slutter å røyke, har økt sjanse for å bli kvitt refluksplagene. Vektreduksjon og røykekutt var også assosiert med økt effekt av den medikamentelle behandlingen.

Den stadig økende forekomsten av reflukssykdom medfører økte kostnader for samfunnet, både på grunn av tapt arbeidsevne og kostnader til utredning og behandling. Videre bidrar trolig reflukssykdom også til at antall personer med adenokarsinom i distale oesophagus øker. Å redusere vekten og å slutte å røyke kan være aktuelle behandlingsalternativer for personer med reflukssykdom, og kan dessuten forebygge at reflukssykdom oppstår i første omgang.

\section{Eivind Ness-Jensen}

eivind.ness-jensen@ntnu.no

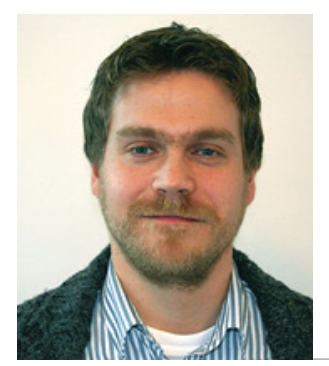

Eivind Ness-Jensen Foto NTNU

Disputas

Eivind Ness-Jensen disputerte for ph.d.-graden ved NTNU 25.2.2014. Tittelen på avhandlingen er Epidemiology of gastro-oesophageal reflux. A prospective population-based cohort study: The HUNT study. 